\title{
Aspekty doświadczania bólu w grupie pielęgniarek anestezjologicznych w zależności od wybranych zmiennych socjodemograficznych
}

\section{The experience of pain in the group of nurse anaesthetists depending on selected socio-demographic variables}

\author{
EWA SZCZECH ${ }^{1}$, ANNA RASZKA²,3, AGNIESZKA PIERNIKOWSKA4, \\ KLAUDIA DASZUTA 4
}

\footnotetext{
${ }^{1}$ Regionalny Szpital Specjalistyczny im. dr Władysława Biegańskiego w Grudziądzu

210 Wojskowy Szpital Kliniczny z Polikliniką w Bydgoszczy

${ }^{3}$ Zakład Pielęgniarstwa Neurologicznego i Neurochirurgicznego CM w Bydgoszczy UMK w Toruniu, Studia doktoranckie

${ }^{4}$ Wojewódzki Szpital Specjalistyczny im. błogosławionego księdza Jerzego Popiełuszki we Włocławku
}

DOI: http://dx.doi.org/10.21784/IwP.2017.020

ISSN: 2541-1846

\section{Streszczenie:}

Wstęp. Dolegliwości bólowe towarzyszą człowiekowi na każdym etapie jego życia. Szacuje się, że w Polsce każdego roku z powodu bólu cierpi 34 miliony osób, z czego aż u 7 milionów odczuwane doznania bólowe mają charakter przewlekły. Na subiektywną ocenę dolegliwości bólowych ma wpływ min. postawa wobec bólu, wcześniejsze doznania bólowe, indywidualne cechy osobowości, stan emocjonalny, sytuacja życiowa.

Cel. Celem niniejszej pracy była analiza charakteru pojawiających się dolegliwości bólowych w grupie pielęgniarek anestezjologicznych w odniesieniu do wybranych zmiennych socjodemograficznych.

Materiał i metody. W badaniu uczestniczyło 70 pielęgniarek zatrudnionych w Regionalnym Szpitalu Specjalistycznym im. dr Władysława Biegańskiego 
w Grudziądzu. W procedurze badawczej wykorzystany został autorski kwestionariusz ankiety. Wyniki badań poddano analizie statystycznej.

Wyniki. Wraz zaawansowaniem wieku oraz długością stażu pracy dolegliwości bólowe $\mathrm{w}$ badanej grupie pielęgniarek pojawiały się $\mathrm{z}$ większą częstotliwością (kilka razy w miesiącu). Ponadto wraz ze stażem pracy wzrastał także czas trwania dolegliwości bólowych, utrzymujących się przez kilka godzin.

Wnioski. Wiek i staż pracy istotnie wpływają na pojawianie się dolegliwości bólowych w grupie pielęgniarek anestezjologicznych.

Słowa kluczowe: staż pracy, wiek, ból, pielęgniarka anestezjologiczna

\begin{abstract}
:
Introduction. Pain is present and accompanies people at all stages of life. The estimated number of people suffering from pain is 34 million yearly. 7 milion out of this number claim the pain to be chronic pain. Subjective pain assesment is influenced by attitude towards pain, previous experience with pain, personal features, emotional state and life situations.
\end{abstract}

Aim. The aim of the study was to analyse the nature of pain in the group of nurse anaesthetists in raltion to selected socio-demographic variables.

Material and methods. The study comprised 70 nurses from Specialist Hospital of dr Wladyslaw Bieganski in Grudziądz. The study instrument was self -created survey questionnare. The results were subjected to statistical analysis.

Results. Pain occurs more often (a few times a month ) with advanced age and job tenure. Pain was experienced for loger periods of time with longer job tenure.

Conclusions. Age and job tenure significantly affect the occurrence of pain among nurse anaesthetists.

Keywords: job tenure, age, pain, nurse anaesthetists

\title{
Wstęp
}


$\mathrm{Na}$ występowanie dolegliwości bólowych wpływa wiele elementów, do których można zaliczyć czynniki związane z jednostką chorobową (objawy choroby zasadniczej, powikłania dotyczące prowadzonego leczenia), czynniki zewnętrzne, inaczej określane społeczne, których przykładem są sytuacje życiowe, społecznoekonomiczne czy wsparcie rodziny oraz czynniki wewnętrzne, nazywane również psychologicznymi, do których można zaliczyć przyjętą postawę wobec bólu, wcześniejsze doznania bólowe, posiadane cechy osobowości czy stan emocjonalny [1]. Ocena piątego parametru życiowego, jakim jest ból powinna być nieodzownym elementem oceny stanu zdrowia każdego chorego.

Ból jest nie tylko problemem dotykającym hospitalizowanych pacjentów, ale również coraz częściej dotyczy on personelu medycznego.

Dolegliwości bólowe są najczęstszym symptomem występującym w medycynie. Pełnią w życiu każdego człowieka funkcję ostrzegawczo - ochronną. Alarmują one organizm przed zagrażającym (na skutek choroby czy urazu) uszkodzeniem tkanek i powodują odruchową oraz behawioralną odpowiedź, mającą na celu zminimalizowanie następstw tego uszkodzenia [2].

Celem badań była analiza charakteru pojawiających się dolegliwości bólowych $\mathrm{w}$ grupie pielęgniarek anestezjologicznych w odniesieniu do wybranych zmiennych socjodemograficznych.

\section{Materiał i metody}

Badania przeprowadzono wśród 70 pielęgniarek anestezjologicznych pracujących na Oddziale Anestezjologii i Intensywnej Terapii oraz na Oddziale Anestezjologii i Intensywnej Terapii dla Dzieci w Regionalnym Szpitalu Specjalistycznym im. dr Władysława Biegańskiego w Grudziądzu, z zastosowaniem metody sondażu diagnostycznego i kwestionariusza ankiety konstrukcji własnej. Udział $\mathrm{w}$ badaniach był dobrowolny. Zgodę na ich 
przeprowadzenie uzyskano od respondentów, Dyrekcji Szpitala oraz Komisji Bioetycznej. Wyniki badań poddano analizie statystycznej.

\section{Wyniki}

Badana grupa to w większości kobiety, stanowiły one $97,1 \%$ respondentów. $Z$ analizy danych wynika, że mężczyźni pracują tylko na Oddziale Anestezjologii i Intensywnej Terapii i stanowią oni 4,3\% poddanej badaniu grupy (2 osoby). Średnia wieku respondentów wynosiła 42 lata. Odchylenie standardowe stanowi ponad $16,4 \%$ wartości średniej, co świadczy o nieznacznym zróżnicowaniu wiekowym w badanej grupie pielęgniarek. Starszymi okazali się badani z OIT, ze średnią wieku ponad 52 lata, natomiast średnia wieku respondentów z OITP wynosiła niespełna 41 lat. Wiek minimalny wobu grupach był zbliżony, niższy - w grupie OIT (24 lata). Maksymalny wiek był zróżnicowany, wyższy również w grupie OIT (58 lat). Respondentów podzielono na trzy grupy wiekowe: do 40 lat, 41 - 45 lat oraz 46 - 58 lat. Najliczniejszą grupę stanowili badani w wieku 41-45 lat (29 osób - 41,4\%), a najmniej liczną w wieku 46-58 lat (19 osób -27,1\%). W grupie respondentów do 40 roku życia znalazły się 22 osoby $(31,4 \%)$. Z Oddziału Anestezjologii i Intensywnej Terapii najliczniejszą grupę stanowili ankietowani w wieku 41-45 lat (18 osób -39,1\%). W pozostałych grupach wiekowych znalazło się po 14 osób (odpowiednio po 30,4\%). Podobnie w Oddziale Anestezjologii i Intensywnej Terapii dla Dzieci najliczniejszą grupę stanowiły osoby w wieku 41-45 lat (11 osób -45,8\%). Najmniej liczną grupą byli respondenci w wieku 46-58 lat (5 osób - 20,8\%). W grupie respondentów do 40 roku życia znalazło się 8 osób (33,3\%).

Najliczniejszą grupę wśród badanych stanowiły osoby legitymujące się posiadaniem tytułu licencjata pielęgniarstwa (52 osoby - 74,3\%), a najmniej liczną pielęgniarki dyplomowane (2 osoby $-2,9 \%)$. Tytuł magistra pielęgniarstwa posiadało 16 osób $(22,9 \%)$. Zarówno na oddziale OIT jaki i na OITP najliczniejszą grupę tworzyły 
pielęgniarki z tytułem licencjata pielęgniarstwa, a najmniej liczną ankietowani, którzy ukończyli Liceum Medyczne lub Studium Medyczne.

Pod względem kwalifikacji zawodowych najliczniejszą grupę stanowili ankietowani, którzy ukończyli kurs kwalifikacyjny z pielęgniarstwa anestezjologicznego i intensywnej opieki (31 osób 44,3\%). Tylko 1 osoba nie ukończyła żadnego kursu kwalifikacyjnego. Z kolei 15 osób $(32,6 \%)$ ukończyło specjalizację z pielęgniarstwa anestezjologicznego i intensywnej opieki a 8 osób było w trakcie jej realizacji $(17,4 \%)$. W oddziale Anestezjologii i Intensywnej Terapii najliczniejszą grupę tworzyli absolwenci kursu kwalifikacyjnego z pielęgniarstwa anestezjologicznego i intensywnej opieki (23 osoby 50,0\%). Z kolei w Oddziale Anestezjologii i Intensywnej Terapii dla Dzieci najliczniejszą grupą były pielęgniarki posiadające specjalizację z pielęgniarstwa anestezjologicznego i intensywnej opieki (9 osób $(37,5 \%)$ lub w trakcie jej realizacji (6 osób - 25\%).

Kolejną zmienną socjodemograficzną, która posłużyła do scharakteryzowania badanej grupy pielęgniarek był staż pracy. Średni staż pracy ankietowanych wynosił niespełna 20 lat. Odchylenie standardowe stanowi ponad 36,5\% wartości średniej, co świadczy o bardzo dużym zróżnicowaniu grupy pod tym względem. Dłuższym stażem pracy charakteryzowali się respondenci z oddziału OIT, ze średnią długością pracy ponad 20 lat, w stosunku do średniej długości stażu pracy badanych z OITP, która wynosiła niespełna 19 lat. Minimalna długość stażu jest identyczna dla obu grup i wynosi 2 lata, a maksymalna jest zróżnicowana i wyższa w grupie OIT (35 lat).

Najliczniejszą grupę stanowili respondenci, których długość stażu pracy mieściła się w przedziale od 21-25 lat (26 osób -37,1\%), a najmniej liczną pielęgniarki, których staż mieścił się w granicach 26 do 35 lat (12 osób -37,1\%). W OIT, najliczniejszą grupę tworzyli ankietowani, których staż pracy wynosił 21 do 25 lat (17 osób (37,0\%), a najmniej liczną z kolei ci, których staż mieścił się w granicach 26 do 35 lat (9 osób -19,6\%). Podobne wyniki dotyczyły 
respondentów z OITP - odpowiednio 9 osób (37,5\%) oraz 3 osoby $(12,5 \%)$.

Sprawdzono czy uzyskane wyniki pozostają w korelacjach $\mathrm{z}$ wybranymi zmiennymi socjodemograficznymi takimi jak miejsce pracy, wiek, wykształcenie respondentów, staż pracy oraz posiadane kwalifikacje zawodowe. Do analizy zastosowano test U- MannaWhitneya, służący do porównywania dwóch niezależnych od siebie grup. Rozpatrując zmienne demograficzne takie jak wiek i staż pracy badanych wykorzystano test korelacji rang Spearmana. Z kolei do analizy kwalifikacji zawodowych wykorzystano test rang KruskalaWallisa, służący do porównania wielu niezależnych od siebie grup. Jednocześnie przyjęto poziom istotności $\mathrm{p} \leq 0,05$ jako istotny statystycznie oraz ustanowiono hipotezę zerową $\left(\mathrm{H}_{0}\right)$, że nie ma różnicy wśród badanych grup.

Przeprowadzona korelacja pomiędzy częstością występowania dolegliwości bólowych, a miejscem pracy respondentów wykazała istotne różnice statystyczne. Ze względu na ustalony poziom istotności $(\mathrm{p}<0,05)$, odnotowano istotną statystycznie różnicę pomiędzy częstością występowania dolegliwości bólowych, a miejscem pracy ankietowanych. Doznania bólowe wśród respondentów pojawiają się najczęściej raz na kilka miesięcy $(62,5 \%$ badanych) i dotykają istotnie częściej pielęgniarek pracujących na Oddziale Anestezjologii i Intensywnej Terapii dla Dzieci, niż pielęgniarek $\mathrm{z}$ Oddziału Anestezjologii i Intensywnej Terapii.

Wiek respondentów pozostawał $\mathrm{w}$ istotnej statystycznie współzależności pomiędzy wynikami częstości występowania dolegliwości bólowych $(\mathrm{p}<0,05)$. Najwięcej ankietowanych w wieku do 40 lat zaznaczyło, że dolegliwości bólowe występują u nich raz na kilka miesięcy (15 osób - 88,2\%). Najmniej stwierdziło, że ma to miejsce codziennie (1 osoba - 4,5\%). Najwięcej badanych w wieku 41-45 lat wskazało, że doznania bólowe występują u nich kilka razy w miesiącu (14 osób - 48,3\%). Tylko jedna pielęgniarka w tej grupie wiekowej $(3,4 \%)$ stwierdziła, że odczuwa ból codziennie. Wśród respondentów 
w wieku 46-58 lat, najwięcej osób stwierdziło, że dolegliwości bólowe występują u nich raz na kilka miesięcy (8 osób - 42,1\%) lub kilka razy w tygodniu (7 osób -36,8\%). Tylko jedna osoba $(5,3 \%)$ wskazała, że odczuwa ból codziennie.

W zakresie wykształcenia nie odnotowano istotnych statystycznie różnic w odniesieniu do badanej grupy a odczuwanych doznań bólowych oraz sposobów radzenia sobie z bólem, znajomości skutecznych metod jego leczenia.

Natomiast staż pracy respondentów pozostawał $\mathrm{w}$ istotnej statystycznie $(\mathrm{p}<0,05)$ korelacji pomiędzy częstością występowania i czasem trwania dolegliwości bólowych $\mathrm{w}$ objętej badaniami grupie pielęgniarek.

Najwięcej ankietowanych, których staż pracy wynosił do 15 lat stwierdziło, że dolegliwości bólowe występują u nich raz na kilka miesięcy (11 osób -73,3\%). Pozostali respondenci w tej grupie wskazali, że odczuwają ból kilka razy w miesiącu (4 osoby -26,7\%). Najwięcej badanych, których staż pracy wynosił 16-20 lat potwierdziło, że doznania bólowe występują u nich kilka razy w miesiącu (8 osób 47,1\%), a najmniej, że codziennie lub kilka razy w tygodniu (po 1 osobie - odpowiednio po 5,9\%). Pielęgniarki posiadające staż pracy od 21 do 25 lat stwierdziły, że dolegliwości bólowe występują u nich raz na kilka miesięcy (11 osób - 42,3\%) lub kilka razy w miesiącu (10 osób -38,5\%), a tylko 1 osoba (3,8\%), że ma to miejsce codziennie. Najliczniejsza grupa pielęgniarek anestezjologicznych ze stażem pracy od 26 do 35 lat stwierdziła, że doznania bólowe występują u nich kilka razy w tygodniu (5 osób - 41,7\%) lub raz na kilka miesięcy (4 osoby $33,3 \%)$. Tylko 1 osoba (8,3\%) w tej grupie wskazała, że ból towarzyszy jej codziennie. Analizując powyższe dane, można stwierdzić, że wraz ze wzrostem okresu stażu pracy, wzrasta czas trwania dolegliwości bólowych.

Nie odnotowano istotnych statystycznie różnic między posiadanymi przez respondentów kwalifikacjami zawodowymi 
a charakterem odczuwanych doznań bólowych i podejmowanymi działaniami na rzecz ich łagodzenia. Wynik odnoszący się do występujących na skutek dolegliwości bólowych reakcji oraz znajomości najbardziej skutecznych metod leczenia bólu znajduje się na granicy istotności statystycznej.

\section{Dyskusja}

Ból od niepamiętnych czasów stanowi przedmiot zainteresowania badaczy. Jest doznaniem wielowymiarowym, gdyż oddziałuje na sferę bio-psycho-społeczną oraz subiektywnym, ponieważ uwarunkowany jest wcześniejszymi doświadczeniami z bólem, stopniem pobudzenia emocjonalnego i wiedzy na temat jego przyczyn i konsekwencji jakie za sobą niesie [3].

W analizie wyników badań własnych wykazano korelację pomiędzy częstością występowania dolegliwości bólowych a miejscem pracy, wiekiem i długością stażu pracy badanych. Doznania bólowe częściej występowały u pielęgniarek anestezjologicznych pracujących na Oddziale Anestezjologii i Intensywnej Terapii dla Dzieci.

Współzależność pomiędzy miejscem pracy respondentów a częstością występowania doznań bólowych wykazali w swoich badaniach Bilski B. i Sykutera L., którzy stwierdzili, że dolegliwości bólowe częściej dotykają personelu pielęgniarskiego pracującego na oddziałach zabiegowych i intensywnej opieki [4].

W przeprowadzonych badaniach wyniki wskazują, że wraz ze wzrostem stażu pracy i wieku badanych wzrasta częstość występowania i czas trwania dolegliwości bólowych. Podobne wyniki osiągnęli Baumgart M., Radzimińska A, Szpinda M. i wsp., którzy badali grupę 60 pielęgniarek, pracujących na różnych oddziałach szpitalnych w województwie kujawsko- pomorskim, pod kątem występowania doznań bólowych. Wspomniani autorzy dowiedli, że dolegliwości bólowe nasilają się wraz ze wzrostem stażu pracy [5]. Podobne wyniki 
odnoszące się do wpływu wieku i długości stażu pracy pielęgniarek na odczuwanie doznań bólowych wykazali Pop T. i wsp. w badaniach dotyczących 170 osób (pielęgniarek, lekarzy i fizjoterapeutów), pracujących w oddziałach szpitalnych i przychodniach przyszpitalnych. Wykazali, że wraz ze wzrostem długości stażu pracy i wieku wzrasta odczuwanie bólu [6].

\section{Wnioski}

Analiza wyników badań własnych umożliwiła wyciągnięcie następujących wniosków:

1. W grupie pielęgniarek anestezjologicznych wraz ze wzrostem stażu pracy i ich wieku wzrastała częstość występowania i czas trwania dolegliwości bólowych.

2. Doznania bólowe istotnie częściej dotyczą pielęgniarek pracujących na Oddziale Anestezjologii i Intensywnej Terapii dla Dzieci, niż pielęgniarek z Oddziału Anestezjologii i Intensywnej Terapii.

\section{Bibliografia / Bibliography:}

1. Kowalczuk K., Krajewska- Kułak E., Jankowiak B i wsp.: Zagrożenia zawodowe pielęgniarek, położnych i lekarzy w środowisku pracy. Probl Hig Epidemiol 2008, 89 (2), 211-215.

2. Mielimąka M., Murzyn A.: Zastosowanie techniki hipnozy w terapii bólu. Psychoonkologia 2011, 1, 16-24. 
3. Andruszkiewicz A., Wróbel B., Marzec A. i wsp.: Strategie radzenia sobie $\mathrm{z}$ bólem u pacjentów ze zmianami zwyrodnieniowymi stawu biodrowego. Probl Pielęg 2008, 16 (3), 237-240.

4. Bilski B., Sykutera L.: Uwarunkowania obciążeń układu ruchu i ich konsekwencje zdrowotne wśród pielęgniarek czterech poznańskich szpitali. Med Pr 2004, 55 (5), 411-416.

5. Baumgart M., Radzimińska A., Szpinda M. i wsp.: Dolegliwości bólowe kręgosłupa wśród personelu pielęgniarskiego. Journal of Education, Health and Sport 2015, 5 (9), 633- 643.

6. Pop T., Przysada G., Świder B.: Stopień niesprawności personelu medycznego mierzony kwestionariuszem Oswestry. Przegląd Medyczny Uniwersytetu Rzeszowskiego 2008, 2, 135-141. 